\title{
PROBLEMS AND SOLUTIONS OF ACQUIRING MATHEMATICAL KNOWLEDGE AT UNIVERSITY DURING COVID-19 CRISIS
}

\author{
Natalija Sergejeva ${ }^{1}$, Aivars Aboltins ${ }^{1}$, Svetlana Atslega ${ }^{1,2}$ \\ ${ }^{1}$ Latvia University of Life Sciences and Technologies, Latvia; \\ ${ }^{2}$ Institute of Mathematics and Computer Science, University of Latvia, Latvia \\ natalija.sergejeva@1lu.lv, aivars.aboltins@1lu.lv, svetlana.atslega@1lu.lv
}

\begin{abstract}
Innovation is needed for the 21 st century education around the world. Nowadays, traditional classroom teaching methods, in which the learners passively participate and the teacher controls everything, are no longer relevant. The impact of information and technological change is also visible in the field of education. The meaning of such concepts as education, teachers, learner, learning process is changing. Therefore, it is necessary to diversify learning models. Key components such as face-to-face teaching, effective learning strategies, and the use of learning technologies are common to all practices. Given today's needs and the profile of 'learners', it is obvious that different teaching methods are needed than traditional ones. This is the time of digital students, and if teachers want to teach the younger generation, they should redesign their methods and materials according to the learning style of the learners. This article was designed to assess the impact of COVID 19 on learning through surveys, gathering the views of students and teachers at the Latvia University of Life Sciences and Technologies. The pandemic significantly increased the introduction of distance learning in all areas of training, both at schools and universities. The important point was that this transition took place instantly and a large number of students and teachers were not ready for it. It was seen that the quality of knowledge of a large number of students decreased, because in this situation the usual comfort zone changed. Isolation, the need to plan one's own time, individual work, lack of counselling, etc. played a role. These issues came to the fore among those students whose level of secondary school preparation was insufficient for the requirements of higher education.
\end{abstract}

Keywords: online education, mathematics, engineering students.

\section{Introduction}

The virtual world is often criticized as distracting or avoiding the real physical world. However, when we are hit by a deadly pandemic, the virtual world is survival. The COVID-19 pandemic has caused the greatest disruption to education systems in history, leaving more than 1.2 billion children in more than 190 countries out of the classroom. The closure of schools and other classes has affected 94 percent of the world's students. However, education cannot be interrupted. As a result of the pandemic, education has changed dramatically, especially with the rise of e-learning, where teaching takes place remotely and on digital platforms. Studies show that online learning increases the retention of information and requires less time, which means that the changes in education caused by the coronavirus could be sustained.

Researchers have noted that well-designed course content and motivated interaction between teachers and students, as well as the creation of a sense of community, are among the foundations of effective online learning [1]. It is this feeling that is most lacking now, in these restrictive circumstances. A study focusing on comparing traditional and online learning [2] found that a large proportion of students perceived their online experience as being positive despite multiple problems in the online courses. A similar research also found that students felt that online courses did not have the same value as classroom learning [3] and that students would prefer blended learning, online and face-to-face learning, rather than just online learning [4]. So, students' views on the effectiveness of online learning before the pandemic were very different.

Although some universities used e-learning as an additional method before the pandemic, most of them were not ready for the full online experience. The online learning process needs to be optimized. A study of students' experiences in online courses showed that students believe that teachers need to know how to adapt their lectures to the online environment, rather than simply passing on online information that was usually taught in the traditional way [5]. For several teachers, who were forced to work with students remotely, it initially seemed that the availability of materials for students would be enough. However, the research shows that this aspect (knowledge transfer) is insignificant [6]. Aspects, such as the interaction between the professor and the student, motivating students to work, gaining realtime feedback and changing pedagogical methods following student feedback, are more important. This 
didactic approach allows the educational process to be focused on students, giving them the role of a partner in the educational process.

The Covid-19 pandemic has led to a worldwide shift to online training. The New York Times declared 2012 as the year of the MOOC (Massive Open Online Course), then came the realization that massive open online courses can compete with traditional university courses. Time will tell what the consequences of the extraordinary transition to distance learning formats will be, but there is no doubt that they will appear in the short term. Higher education development experts Philip Altbach and Hans de Wit [7] question whether the pandemic will lead to a technological revolution in higher education, but it is nevertheless clear that the Covid-19 crisis will have a lasting impact on the education system and that the digital role of education will continue to grow in the future, both globally and in Latvia.

In our country, the transition to fully distance learning in accordance with the decision of the Cabinet of Ministers occurred on March 13, 2020, when the state of emergency in Latvia was declared, which lasted until June 9, 2020. At the end of September 2020, the prevalence of Covid-19 in Latvia increased rapidly, thus several regulations of the Cabinet of Ministers were adopted, due to which restrictions were introduced that affected the full-time process in Latvian higher education institutions. For the second time in Latvia, the state of emergency was declared from November 9, 2020 to April 6, 2021, and again the full-time study process in all higher education institutions was completely stopped. It is planned to complete studies remotely during this spring semester at LLU and other higher education institutions in Latvia.

Mathematics is one of the most important subjects, especially for engineering students. Because it is one of the components of STEM (science, technology, engineering, and mathematics). Even in faceto-face training, this has often been a challenge for many students. These difficulties are related both to the previous level of knowledge of mathematics $[8,9,10]$ and to the insufficient use of the Internet resources. Mathematics is currently gaining significant weight, especially in terms of a critical understanding of its application. In order to be sufficiently involved in STEM knowledge and how science works and informs about decisions about a person's health, critical STEM skills are needed. STEM literacy is needed to criticize government social policy decisions that set rules of conduct to limit the spread of COVID-19 [11].

In Latvia, several studies have been conducted on how university students feel during distance learning caused by Covid-19. For example, the Latvian Students' Union conducted such a survey in the first wave in March 2020, surveying approximately 1,600 respondents from various Latvian higher education institutions [12], and the recommendations were prepared and forwarded to all universities and student governments in Latvia. Several Latvian higher education institutions also conducted similar surveys to determine what the situation is at a particular higher education institution. Such a survey of all students at LLU was conducted at the end of April 2020, and its main goal was to identify the main problem situations and issues in the study process. This article analyses a study related to engineering students at LLU and their mathematics course during distance learning.

\section{Materials and methods}

The study was conducted in January-February 2021. To study the challenges of students' mathematics acquisition, LLU students and mathematics teachers at major Latvian universities were interviewed online. In total, 104 LLU students of various engineering specialties participated in the study. This article emphasizes the students' views on the challenges of learning mathematics remotely instead of the usual face-to-face form.

Taking into account that there is currently a second wave of Covid-19 in Latvia, due to which the whole study process takes place remotely in higher education institutions, the respondents were divided into two groups: 1st year students experiencing distance learning for the first time during higher education, and 2nd and 3rd year students, who already have some experience of studying remotely due to the first wave of Covid-19. 47 (45\% of the total number of respondents) 1 st year students and 57 (55\% of the total number of respondents) 2 nd and 3rd year students participated in the study.

The survey included 10 closed-ended and semi-closed-ended questions with suggested answers and 2 open-ended questions. 


\section{Results and discussion}

The efficiency of both the full-time and distance mathematics study process is definitely influenced by the students' previous knowledge base. Therefore, one of the first questions in the student survey was to assess their level of knowledge of mathematics when entering the university (see Fig. 1). The results of the survey show that more than half of the respondents (60 students or 58\%) rate their level of mathematical knowledge as excellent or good.

The successful course of the distance learning process is clearly influenced by the students' technical support. In the first wave of Covid-19 in the spring of 2020, the authors of the study had received information from several students that there were problems with the Internet connection and workload, often with only one information equipment and several users in the household. Therefore, the respondents were offered to evaluate their technical provision in order to study the mathematics study course remotely (see Fig. 2). It turns out that only 4 students (4\%) had insufficient technical support to successfully master the mathematics course, 3 of them were 1 st year students.

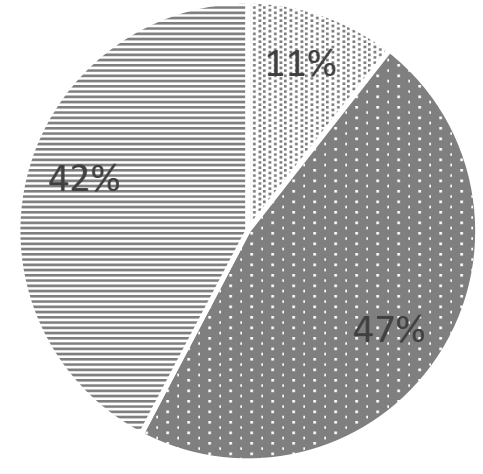

excellent good $\equiv$ satisfactory

\section{Fig. 1. Students' self-assessment of mathematics knowledge}

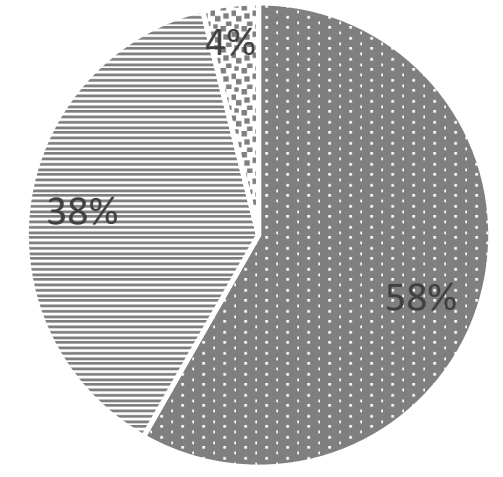

- good $\equiv$ satisfactory : unsatisfactory

The authors of the study felt that it was important to find out the students' opinion on whether the distance learning process has had a positive or negative effect on the students' knowledge and skills, because we have understood from conversations with students that students have diametrically opposite opinions. It was found that 17 students $(16 \%)$ thought that they would have learned the same as during the full-time study process. On the other hand, 69 students $(67 \%)$ thought that they would have learned a little or much more in face-to-face studies, and only 18 students (17\%) thought that they had learned much or a little more during the distance learning than they would have learned in face-to-face studies. The answers to this question, taking into account the division of respondents into two groups, are summarized in Table 1. The table shows the proportion of these students compared to the absolute number of each specific group of students.

Table 1

Students' self-assessment about acquisition of study materials
in the distance learning process and during full-time studies

\begin{tabular}{|c|c|c|c|}
\hline Statement & $\begin{array}{c}\text { 1st year } \\
\text { students }\end{array}$ & $\begin{array}{c}\text { 2nd and 3rd } \\
\text { year students }\end{array}$ & In total \\
\hline $\begin{array}{c}\text { During the distance learning process I learned a lot/a } \\
\text { little more than during the full-time study process. }\end{array}$ & $19 \%$ & $16 \%$ & $17 \%$ \\
\hline $\begin{array}{c}\text { During the distance learning process I learned as } \\
\text { much as during the full-time study process. }\end{array}$ & $15 \%$ & $17 \%$ & $16 \%$ \\
\hline $\begin{array}{c}\text { During the distance learning process I learned a lot/a } \\
\text { little less than during the full-time study process. }\end{array}$ & $66 \%$ & $67 \%$ & $67 \%$ \\
\hline
\end{tabular}


For the authors of the study, as practicing educators, it was important to find out whether the materials and resources prepared and offered by the lecturers were sufficient for the students to take the mathematics course online. 78 respondents (75\%) agreed or agreed more than disagreed, including 36 (77\% of all students in this group) 1st year students and 42 (74\% of all students in this group) 2nd and 3rd year students. Only 14 students (14\%) disagreed or disagreed more than agreed, these students include 7 ( $15 \%$ of all students in this group) 1 st year students and 7 (12\% of all students in this group) 2nd and 3rd year students.

Continuing the topic of the materials used, students had to indicate exactly what tools were used to take the math course remotely. Students, answering this question, had the opportunity to choose the answer between the offered or offer their own option. The most common answers of students to this question are summarized in Table 2, arranged in order, starting with the most frequently given answer. In their daily work (even before the distance learning process) the authors of the study have regularly encountered homework tasks, which have been solved using various software packages currently popular among students (Photomath, Symbolab, etc.). There are both positive and negative aspects to using software packages in everyday work. In the distance learning process, the authors observe both the answers written from the software packages and the fact that students use them to make sure that the tasks are solved correctly. During the face-to-face process, most students of engineering study programs at LLU have the opportunity to check the correctness of solving their homework tasks during the laboratory work, using the Matlab program. During the distance learning studies, the lecturers themselves often offered the students to use the software packages to check the homework and thus motivate themselves either to find mistakes themselves or to ask for the teacher's help.

Table 2

Tools used by students to study mathematics in the distance learning process

\begin{tabular}{|c|c|c|c|}
\hline Statement & $\begin{array}{c}\text { 1st year } \\
\text { students }\end{array}$ & $\begin{array}{c}\text { 2nd and 3rd } \\
\text { year students }\end{array}$ & In total \\
\hline Teacher-led online lectures & $100 \%$ & $100 \%$ & $100 \%$ \\
\hline Teaching materials from Youtube & $21 \%$ & $37 \%$ & $30 \%$ \\
\hline Software packages (Photomath, Symbolab, etc.) & $51 \%$ & $74 \%$ & $64 \%$ \\
\hline Help of a private teacher & $13 \%$ & $11 \%$ & $12 \%$ \\
\hline Books (including e-books) & $15 \%$ & $12 \%$ & $13 \%$ \\
Studying materials from other Latvian universities & $0 \%$ & $5 \%$ & $3 \%$ \\
\hline
\end{tabular}

The transition to the distance learning process took place immediately, surprising the teachers unprepared, but the study process was not interrupted, classes and consultations were provided online. And the big challenge for teachers was to provide students with counselling. LLU mathematics teachers used all available opportunities for this work: both the study environment, e-mail and private communication via WhatsApp. The three most common student answers to this question are summarized in Table 3. In addition to what is shown in the table, telephone calls ( 7 students) and texting (4 students) were used. It should be noted that 1st year students use e-mail and e-learning opportunities much less in communication than older students. This could be explained by entering a new environment and lack of experience. This should also be taken into account when teachers work with the first-year students.

Consequently, the authors of the study were also interested in the question of whether the number of consultations of a mathematics teacher was, in the opinion of the students, sufficient for the acquisition of the mathematics course. It was found that 81 students $(78 \%)$ thought that they were sufficient, 17 students (16\%) thought that the answers were neutral and 6 students $(6 \%)$ thought that they were not enough.

A major challenge, which required both a lot of time and imagination on the part of the teacher, was the organization of the tests at a distance. Both the authors of the study and LLU mathematics colleagues act differently on this issue: some asked students to work with a video camera turned on, some organized individual interviews with each student after completion of the work, some organized test work in levels and interviewed only some students. Teachers believe (this is also confirmed by the results of the teacher 
survey) that it is easier for students to take tests in mathematics during the distance learning process. 61 students (59\%) agree, 27 students (26\%) neither agree nor disagree, and 16 students (15\%) do not agree that it is easier to complete the test at a distance than during full-time studies. When working remotely, students use software packages. As mentioned above, this seems even correct to the authors of the study, because it is only natural to try to immediately check whether the problem is solved correctly, or there are no arithmetical errors, but a much more worrying moment is the use of other people's help during the test. It was found that 83 students (80\%) completed the mathematics tests themselves, they did not need the help of other people, but 21 students (20\%) used such opportunity.

Table 3

Tools used by students to communicate with a math teacher

\begin{tabular}{|c|c|c|c|}
\hline Statement & $\begin{array}{c}\text { 1st year } \\
\text { students }\end{array}$ & $\begin{array}{c}\text { 2nd and 3rd } \\
\text { year students }\end{array}$ & In total \\
\hline Communication with WhatsApp & $66 \%$ & $68 \%$ & $67 \%$ \\
\hline E-learning environment & $31 \%$ & $70 \%$ & $69 \%$ \\
\hline E-mail & $20 \%$ & $60 \%$ & $53 \%$ \\
\hline
\end{tabular}

The experience gained in the distance learning process is undeniably very rich and makes you think about future opportunities to teach and to study mathematics. There are some students who would not have even thought about distance learning and especially about distance learning in the case of mathematics, but after trying they understood that it was possible. During the survey, students, when evaluating their experience, had to assess whether the acquisition of higher mathematics is possible remotely. Their responses are summarized in Table 4.

Table 4

Student's experience studying mathematics remotely in Covid-19 conditions shows that...

\begin{tabular}{|c|c|c|c|}
\hline Statement & $\begin{array}{c}\text { 1st year } \\
\text { students }\end{array}$ & $\begin{array}{c}\text { 2nd and 3rd } \\
\text { year students }\end{array}$ & In total \\
\hline $\begin{array}{c}\text { Both lectures and practical classes in mathematics } \\
\text { could only take place remotely. }\end{array}$ & $42 \%$ & $49 \%$ & $46 \%$ \\
\hline $\begin{array}{c}\text { Lectures in mathematics could take place remotely, } \\
\text { but practical classes should take place in person. }\end{array}$ & $26 \%$ & $30 \%$ & $28 \%$ \\
\hline $\begin{array}{c}\text { Both lectures and practical classes in mathematics } \\
\text { should take place only in person. }\end{array}$ & $32 \%$ & $21 \%$ & $26 \%$ \\
\hline
\end{tabular}

As the last questions of the survey, open-ended questions were asked, inviting students to mention the negative and positive aspects of the distance learning process. In total, 10 students ( 4 of them 1st year students) noted that there were no negative aspects in distance learning, 2 of them especially noted that there were no such aspects in the acquisition of mathematics. In turn, 7 considered ( 5 of them 1 st year students) the exact opposite, they do not see anything positive in distance learning. Students often mentioned in their answers that it is difficult to motivate themselves to study during distance learning (this was mentioned by about $20 \%$ of students); the Internet congestion and excessive computer use; lack of direct contact, which would ensure that the teacher could answer questions faster; increasing amount of independent work. In turn, as a positive aspect many students mentioned the opportunity to watch the lecture again and the opportunity to work at their own pace; time savings, as there is no need to spend time moving between home and university; an opportunity to plan own time. An interesting fact that some students noted that communication with teachers was difficult, but often the opposite was noted that it was easier to communicate with teachers during the distance learning process.

\section{Conclusions}

1. The study concluded that the difference of opinions between the 1st year students and 2nd and 3rd year students is statistically insignificant. The reason for this could be the fact that the 1st year students have experienced distance learning in the 12th grade of secondary school. 
2. Special attention should be paid to the 1st year students. When entering a new university environment, they do not have sufficient skills to communicate with the lecturer. The results showed that they use e-mail and e-learning environment in communication almost 3 times less than the senior students. Their main means of communication is WhatsApp, which they use in practice on a daily basis.

3. The results of the survey showed that students' views are often diametrically opposite on the same issue. The efficiency of the distance learning process is much more dependent on the student himself than the full-time study process.

4. Very important support is psychological support for students, teachers should be explained psychology issues so that they can timely identify at least some of the students' problems and provide timely support.

\section{References}

[1] Sun A., Chen X. Online education and its effective practice: A research review. Journal of Information Technology Education: Research. 2016, 15, pp. 157-190. [online] [31.03.2021] Available at: http://www.jite.org/documents/Vol15/JITEv15ResearchP157-190Sun2138.pdf

[2] Alsaaty, F.M.; Carter, E.; Abrahams, D.; Alshameri, F. Traditional Versus Online Learning in Institutions of Higher Education: Minority Business Students' Perceptions. Bus. Manag. Res. 2016, 5(2), pp. 31-41.

[3] Galy E., Downey C., Johnson J. The Effect of Using E-Learning Tools in Online and CampusBased Classrooms on Student Performance. J. Inf. Technol. Educ., 2011, 10, pp. 209-230.

[4] Tagoe M. Students' Perceptions on Incorporating E-Learning into Teaching and Learning at the University of Ghana. Int. J. Educ. Dev. Using Inf. Commun. Technol., 2012, 8, pp. 91-103.

[5] Sun L., Tang Y., Zuo W. Coronavirus pushes education online. Nat. Mater. 2020, 19, p. 687.

[6] Popa D., Repanovici A., Lupu D., Norel M., Coman C. Using Mixed Methods to Understand Teaching and Learning in COVID 19 Times. Sustainability, 2020, 12(20), pp. 1-20.

[7] Altbach P.G., De Wit H. Post pandemic outlook for HE is bleakest for the poorest. [online] [31.03.2021] Available at: https://www.universityworldnews.com/post.php?story $=20200402152914362$

[8] Sergejeva N., Aboltins A., Strupule L., Aboltina B. Mathematical knowledge in elementary school and for future engineers. 17th International scientific conference "Engineering for rural development": Proceedings, Jelgava, Latvia, May 23 - 25, 2018, pp. 1166-1172.

[9] Aboltins A., Atslega S., Sergejeva N., Strupule L. One of opportunities to reduce student dropouts. 18th International scientific conference "Engineering for rural development": Proceedings, Jelgava, Latvia, May 22-24, 2019, pp. 1941-1946.

[10] Sergejeva N., Aboltins A. Knowledge of mathematics and physics as basis for studies in engineering sciences. 19th International scientific conference "Engineering for rural development": Proceedings, Jelgava, Latvia, May 20-22, 2020, pp. 1302-1307.

[11] Braund M. Critical STEM Literacy and the COVID-19 Pandemic. Preprint, ResearchGate, 2020. [online] [01.04.2021] Available at: https://www.researchgate.net/publication/343696304

[12] Par attālinātām studijām Covid-19 krīzes laikā. Aptaujas rezultātu apkopojums. Marts 2020. (in Latvian) [online] [31.03.2021] Available at: https://www.lsa.lv/wp-content/uploads/2020/04/Parattalinatam-studijam-Covid-19-krizes-laika.pdf 